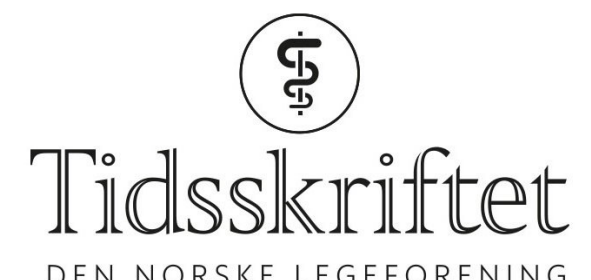

DEN NORSKE LEGEFORENING

\title{
Få metaanalyser med individuelle pasientdata
}

FRA ANDRE TIDSSKRIFTER

KETIL SLAGSTAD

Tidsskriftet

Det er fortsatt vanskelig å få tilgang til individuelle pasientdata i metaanalyser.

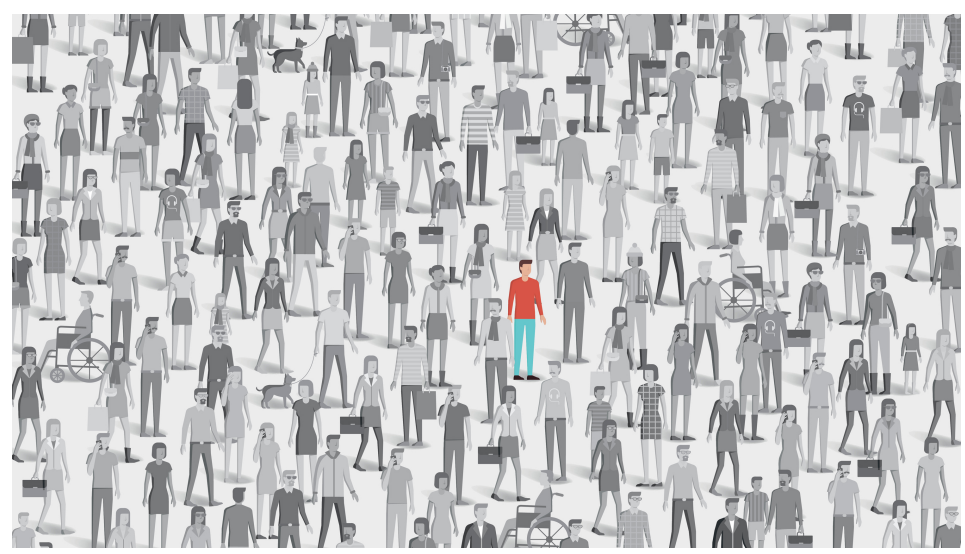

Illustrasjon: Thinkstock

Metaanalyser basert på individuelle pasientdata anses som gullstandarden for å besvare kliniske forskningsspørsmål. Slike studier har flere fordeler sammenlignet med tradisjonelle metaanalyser med aggregerte data. Det blir publisert flere og flere metaanalyser med individuelle pasientdata, men det kan være vanskelig å få tak i disse etter at studien er avsluttet og resultatene publisert.

I en studie i tidsskriftet $B M J$ ble alle metaanalyser med individuelle pasientdata publisert på engelsk i perioden 1987-2015 studert, det vil si til sammen 760 metaanalyser (1). I bare $25 \%$ av disse fikk man tilgang til alle individuelle pasientdata i ettertid, og i bare drøyt $40 \%$ av studiene fikk forskerne tilgang til $80 \%$ eller mer av de aktuelle pasientdataene. Det var ingen sammenheng mellom hvem som finansierte studiene og datatilgangen. Blant de vanligste grunnene til manglende tilgang var at dataene ikke var tilgjengelige, at forskerne ikke var tilgjengelige, at forskerne ikke ønsket å dele dataene med andre og at dataene var forsvunnet eller blitt ødelagt. Resultatene tyder altså på tilgangen til individuelle pasientdata i metaanalyser ikke er blitt bedre.

- Dette er en godt utført studie, som dessverre viser at det ikke har vært noen bedring over tid i hva gjelder adgangen i ettertid til pasientdata i metaanalyser basert på individuelle data, sier Signe Flottorp, som er avdelingsdirektør ved Folkehelseinstituttet. - Metaanalyser med individuelle pasientdata kan gi de mest pålitelige resultatene for kliniske spørsmål, 
forutsatt at de er gjennomført med gode systematiske metoder. Det er derfor viktig å støtte alle initiativ som kan sikre at data fra kliniske studier blir delt med andre forskere. Samtidig må vi sikre at slik datadeling er forsvarlig og gjennomførbart uten at det blir for ressurskrevende for forskerne, sier Flottorp.

LITTERATUR:

1. Nevitt SJ, Marson AG, Davie B et al. Exploring changes over time and characteristics associated with data retrieval across individual participant data meta-analyses: systematic review. BMJ 2017; 357: j1390.

Publisert: 26. juni 2017. Tidsskr Nor Legeforen. DOI:10.4045/tidsskr.17.0397

(C) Tidsskrift for Den norske legeforening 2020. Lastet ned fra tidsskriftet.no 